\title{
PENERAPAN COACHING UNTUK MENINGKATKAN KOMPETENSI KEPALA SEKOLAH DALAM SUPERVISI AKADEMIK PADA SMP BINAAN DINAS PENDIDIKAN KOTA BANJARMASIN
}

\author{
Abdul Majid ${ }^{1}$ \\ 1. Pengawas SMP Disdik Kota Banjarmasin \\ majidpengawas03bjm@gmail.com
}

\begin{abstract}
ABSTRAK
Penelitian Tindakan Sekolah (PTS) dengan menggunakan pendekatan coaching adalah suatu proses membantu seseorang agar bisa belajar sehingga terjadi perkembangan dalam dirinya dan diikuti peningkatan kinerjanya. Penelitian ini dilaksanakan pada 3 (tiga) sekolah binaan peneliti yaitu SMP Anggrek Banjarmasin, SMP Kristen Kanaan Banjarmasin, dan SMP Muhammadiyah 2 Banjarmasin yang dilaksanakan dari bulan Januari 2017 sampai dengan April 2017. Adapun tujuan dari penelitian ini adalah untuk mengetahui apakah kompetensi kepala sekolah dalam supervisi akademik akan meningkat melalui coaching pada SMP binaan Dinas Pendidkan Kota Banjarmasin? Teknik pengumpulan data dalam penelitian ini dilakukan melalui observasi, metode dokumentasi, dan melalui kuesioner. Sedangkan teknik analisis data dipilah menjadi dua yaitu data kuantitatif dan data kualitatif. Hasil penelitian menunjukkan adanya peningkatan kompetensi kepala sekolah dalam supervisi akademik melalui coaching. Dengan dilengkapinya dokumen supervisi akademik yakni perencanaan, pelaksanaan, evaluasi dan tindak lanjut pada masing-masing kepala sekolah. Peningkatan secara signifikan dapat dilihat dari $66,67 \%$ pada siklus I, meningkat menjadi 83,33\% pada siklus II. Disarankan agar Pengawas sekolah: 1). dapat menerapkan teknik coaching kepada kepala sekolah binaannya dalam melengkapi dan melaksanakan supervisi akademik di sekolah; 2). senantiasa melakukan berbagai inovasi dalam kegiatan pengawasan dalam rangka peningkatan kompetensi kepala sekolah yang pada gilirannya akan berdampak pada meningkatnya kualitas pembelajaran.
\end{abstract}

\section{Kata Kunci: Coaching Kompetensi Kepala Sekolah, Supervisi Akademik}

\section{PENDAHULUAN}

\section{A. Latar Belakang Masalah}

Peraturan Pemerintah Nomor 74 Tahun 2008 tentang Guru Pasal 54 ayat (8) butir d menyatakan bahwa guru yang diangkat dalam jabatan Pengawas Satuan Pendidikan melakukan tugas pembimbingan dan pelatihan profesional guru dan tugas pengawasan. Tugas pengawasan yang dimaksud adalah melaksanakan kegiatan pengawasan akademik dan manajerial. Hal ini seiring dengan Permen PAN dan RB nomor 14 Tahun 2016 tentang Perubahan atas Peraturan Menteri Pendayagunaan Aparatur Negara dan Reformasi Birokrasi Nomor 21 Tahun 2010 tentang Jabatan Fungsional Pengawas Sekolah dan Angka Kreditnya Bab II Pasal 5 yang menyatakan bahwa tugas pokok Pengawas Sekolah adalah melaksanakan 
tugas pengawasan akademik dan manajerial pada satuan pendidikan yang meliputi penyusunan program pengawasan, pelaksanaan pembinaan, pemantauan pelaksanaan Delapan Standar Nasional Pendidikan, penilaian, pembimbingan dan pelatihan profesional guru, evaluasi hasil pelaksanaan program pengawasan, dan pelaksanaan tugas kepengawasan di daerah khusus. Dengan demikian, pengawas sekolah dituntut mempunyai kualifikasi dan kompetensi yang memadai untuk mampu melaksanakan tugas pengawasan. Kualifikasi dan kompetensi yang dimaksud adalah kompetensi sebagaimana telah diatur dalam Peraturan Menteri Pendidikan Nasional Nomor 12 Tahun 2007, yaitu kompetensi kepribadian, kompetensi supervisi akademik, kompetensi supervisi manajerial, kompetensi evaluasi pendidikan, kompetensi penelitian dan pengembangan, dan kompetensi sosial.

Kemudian, untuk menjadi seorang pengawas sekolah yang profesional dalam melaksanakan tugas pokok kepengawasan akademik dan manajerial tersebut, pengawas sekolah harus memiliki kompetensi prasyarat yakni 1) pengawasan sekolah, 2) pengembangan profesi, 3) teknis operasional, dan 4) wawasan kependidikan. Dengan dimilikinya kompetensi prasyarat tersebut, pengawas sekolah dapat membantu kepala sekolah dalam mengarahkan tujuan yang akan dicapai secara efektif, efisien, dan produktif. (Kementerian Pendidikan Nasional, 2011: 6)

Dalam buku Supervisi Akademik (Kementerian Pendidikan dan Kebudayaan, 2014b: 121) dinyatakan bahwa supervisi akademik merupakan serangkaian kegiatan membantu guru mengembangkan kemampuannya mengelola proses pembelajaran dalam pencapaian tujuan pembelajaran. Sehingga tujuan pembelajaran yang sudah ditetapkan oleh pemerintah pusat maupun daerah dapat dicapai melalui adanya proses supervisi akademik yang sesuai aturan dan tepat sasaran tanpa harus membeda-bedakan subyek yang ada.

Dalam menjalankan supervisi akademik ini, seorang kepala sekolah harus mampu menyusun program supervisi akademik, melaksanakan supervisi akademik terhadap guru dengan menggunakan pendekatan dan teknik supervisi yang tepat, serta menilai dan menindaklanjuti kegiatan supervisi akademik tersebut dalam rangka peningkatan profesionalisme guru. Peran kepala sekolah dalam supervisi akademik ini sangat penting. Jika supervisi ini tidak dilaksanakan sesuai aturan yang sudah ditetapkan, maka akan berdampak buruk bagi siswa, guru, dan akhirnya sekolah.

Berdasarkan hasil penialaian kinerja kepala sekolah yang dilakukan peneliti pada 8 (delapan) sekolah binaan diperoleh rata-rata nilai pada aspek supervisi akademik adalah 68,75 dan masih berada di bawah target pencapaian yang ditetapkan pada program tahunan kepengawasan yaitu 80,00. Dari hasil analisis terhadap dokumen yang dimiliki oleh para kepala sekolah umumnya program, jadwal, instrumen dan laporan hasil supervisi akademik masih amburadul. Apalagi dalam melaksanakan supervisi akademik terhadap guru, kepala sekolah tidak memiliki dokumen yang lengkap berapa jumlah guru yang sudah disupervisi untuk dijadikan dasar menilai dan menindaklanjuti kegiatan supervisi akademik. Ini berarti kepala sekolah masih belum kompeten dalam supervisi akademik. Hal ini perlu ditindaklanjuti oleh pengawas untuk meningkatkan kompetensi kepala sekolah dalam supervisi akademik. 
Bahan prosedur pelaksanaan supervisi yang diberikan oleh pengawas sekolah kepada kepala sekolah ternyata tidak cukup memberikan pemahaman yang jelas. Perlu dilakukan pendekatan yang lebih mendalam sehingga kepala sekolah tidak hanya merasa cukup melakukan supervisi akademik di sekolahnya, akan tetapi dibutuhkan pengecekan secara rinci oleh pengawas sekolah apa saja yang telah dibuat oleh kepala sekolah untuk menyusun perencanaan supervisi akademik yang sistematis dan terarah.

Dari masalah di atas, penulis memberikan solusi untuk meningkatkan kemampuan kepala sekolah dalam supervisi akademik dengan cara mengadakan kunjungan rutin yang sudah dinegosiasikan dengan melakukan coaching kepada 3 (tiga) kepala sekolah binaannya. Parsloe dan Wray (dalam Kementerian Pendidikan dan Kebudayaan, 2014a: 100) menyatakan bahwa coaching adalah suatu proses membantu seseorang agar bisa belajar sehingga terjadi perkembangan dalam dirinya dan diikuti peningkatan kinerjanya. Kemudian selajutnya, coaching merupakan salah satu strategi pengembangan kapasitas sekolah/madrasah. Serta coaching dapat dilakukan untuk memperbaiki kinerja perorangan, organisasi maupun sistem sekolah/madrasah (Kementerian Pendidikan dan Kebudayaan, 2014a: 16). Dengan diterapkannya coaching ini kepada kepala sekolah, kemampuan kepala sekolah diharapkan dapat ditingkatkan dan dikembangkan untuk menjadi lebih baik.

Penelitian Tindakan Sekolah (PTS) ini penting dilakukan agar ada peningkatan kompetensi kepala sekolah terutama dalam supervisi akademik. Berdasarkan dari latar belakang di atas, maka diambil judul "Penerapan Coaching untuk Meningkatkan Kompetensi Kepala Sekolah dalam Supervisi Akademik pada SMP Binaan Dinas Pendidkan Kota Banjarmasin.

\section{B. Rumusan Masalah}

Berdasarkan dari latar belakang di atas, maka masalah yang diangkat adalah, "Apakah kompetensi kepala sekolah dalam supervisi akademik dapat ditingkatkan melalui coaching pada SMP binaan Dinas Pendidkan Kota Banjarmasin?

\section{Tujuan Penelitian}

Adapun tujuan dari penelitian ini adalah untuk mengetahui peningkatan kompetensi kepala sekolah dalam supervisi akademik melalui coaching pada SMP binaan Dinas Pendidkan Kota Banjarmasin.

\section{Manfaat Penelitian}

Manfaat penelitian ini adalah sebagai berikut:

1. Bagi Siswa

2. Bagi Guru

3. Bagi Kepala Sekolah
: Mendapatkan pelayanan proses pembelajaran di kelas yang lebih efektif dan efisien.

: Kompetensi guru dalam Proses Belajar Mengajar lebih meningkat.

Merupakan salah satu upaya untuk membantu peningkatan kompetensi kepala sekolah dalam bidang akademik 
4. Bagi Sekolah $\quad$ : meningkatkan kualitas pembelajaran yang pada gilirannya akan meningkatkan kualitas pendidikan di sekolah

5. Bagi Pengawas : sebagai salah satu bentuk peningkatan Sekolah kompetensi pengawas sekolah pada aspek penelitian dan pengembangan profesi

\section{METODE PENELITIAN}

\section{A. Setting Penelitian}

\section{Subjek Penelitian}

Subjek dari penelitian ini adalah 3 (tiga) kepala sekolah dibawah binaan Dinas Pendidikan Kota Banjarmasin, yaitu kepala sekolah SMP Anggrek Banjarmasin, SMP Muhammadiyah 2 Banjarmasin, dan SMP Kristen Kanaan Banjarmasin.

\section{Lokasi Penelitian}

Penelitian ini dilakukan pada 3 (tiga) sekolah binaan dan berada pada wilayah kecamatan yang sama yaitu kecamatan Banjarmasin Tengah berada di wilayah Dinas Pendidikan Kota Banjarmasin.

\section{Waktu Penelitian}

Waktu yang dilaksanakan untuk melakukan penelitian ini adalah 4 (empat) bulan dimulai dari bulan Januari 2017 sampai dengan April 2017.

\section{B. Desain Penelitian}

Penelitian tindakan ini dilaksanakan dalam 2 siklus. Adapun jalur kegiatan tindakan dapat dilihat pada Gambar 3.1.

\section{Langkah-langkah PTS}
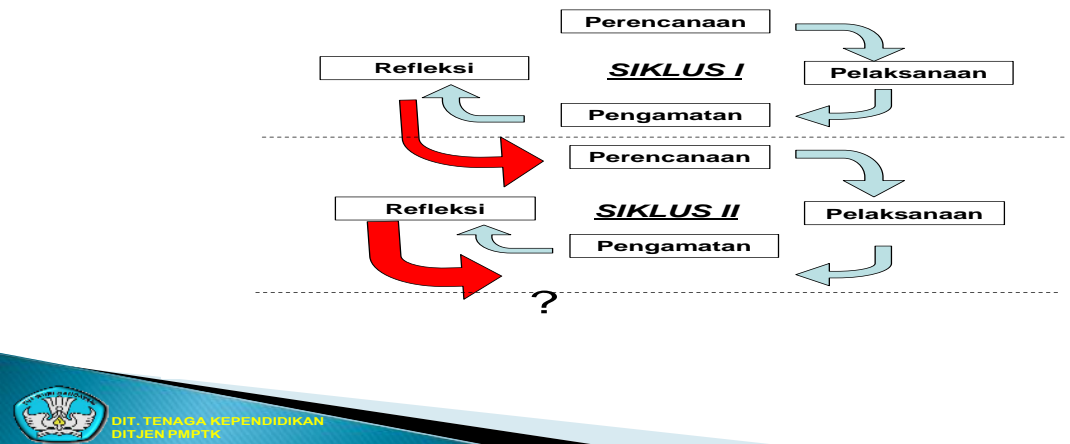

Gambar 3.1 Desain Penelitian

\section{Prosedur Penelitian}

Jenis tindakan dalam penelitian ini adalah action research yang bersifat refleksi, yaitu penelitian tindakan deskriptif dengan supervisi langsung terhadap 3 (tiga) orang kepala sekolah yang dijadikan sebagai subyek penelitian pada 3 (tiga) SMP binaan di Kota Banjarmasin. 
Penelitian ini dilakukan dalam 2 (dua) siklus, yang masing-masing siklusnya dilakukan dalam 4 (empat) kegiatan yakni perencanaan, pelaksanaan, pengamatan, dan refleksi (Arikunto, Suhardjono, dan Supardi, 2010:74). Rangkaian tahap-tahap penelitian tersebut dilakukan dari awal sampai akhir. Penelitian ini merupakan penelitian yang dilakukan secara berulang-ulang dan berkelanjutan sampai tujuan penelitian tercapai.

Adapun metode yang digunakan dalam penelitian ini adalah metode deskriptif dimana untuk melihat peningkatan kompetensi kepala sekolah dengan menggunakan teknik persentase dari siklus ke siklus. Melalui metode ini, penulis berupaya menjelaskan data yang penulis kumpulkan melalui wawancara, pengamatan, dan diskusi yang berupa persentase.

\section{Indikator Keberhasilan Tindakan}

Untuk mengetahui keberhasilan penelitian tindakan sekolah (PTS) melalui penerapan coaching, ditetapkan indikator keberhasilan penelitian sebagai berikut : "Penelitian ini dianggap berhasil : jika dan hanya jika nilai kualitas kinerja kepala sekolah lebih dari atau sama dengan $80 \%$ sudah memperoleh nilai kinerja baik/sangat baik dalam merencanakan, melaksanakan, menilai, dan mengevaluasi guru dalam kompetensi supervisi akademik".

\section{E. Teknik Pengumpulan Data}

Data penelititan ini dikumpulkan melalui pengamatan langsung serta dengan menggunakan instrumen pengamatan untuk mengumpulkan data.

\section{Observasi}

Observasi dilakukan dengan 2 (dua) cara, yakni:

a. Observasi non sistematis dilakukan ketika pengamatan dilakukan tanpa menggunakan instrumen pengamatan. Penulis hanya melakukan pemantauan secara langsung.

b. Observasi sistematis dilakukan ketika pengamatan dilakukan dengan menggunakan instrumen pengamatan untuk mengetahui hasil yang sudah dilakukan oleh kepala sekolah sebelumnya.

\section{Metode Dokumentasi}

Dalam penelitian ini, penulis mengumpulkan dan mencermati bendabenda tertulis yang berhubungan dengan supervisi akademik berupa dokumen rencana supervisi akademik, instrumen Penilaian Kinerja Guru (PKG), dan berkas-berkas lainnya yang mendukung pengumpulan data yang diharapkan oleh penulis.

\section{F. Teknik Analisis Data}

Hasil dari pengumpulan data yang bersumber dari observasi, dokumentasi dan kuesioner, penulis melakukan analisis dan memilahnya menjadi 2 (dua) kelompok, yaitu: data kualitatif dan data kuantitatif.

1. Data Kuantitatif: merupakan data dalam bentuk angka yang diambil dari hasil monitoring dan coaching serta format hasil pembelajaran yang diharapkan. 
2. Data Kualitatif: merupakan data dalam bentuk kategori berdasarkan kualitas objek yang diteliti, daimbil dari instrumen penilaian diri bagi coachee dan instrumen penilaian proses coaching.

\section{HASIL DAN PEMBAHASAN}

\section{A. Hasil Penelitian}

1. Siklus I

Dari hasil pengamatan siklus pertama, dapat dilihat pada pelaksanaan topik perencanaan Supervisi Akademik sudah dilaksanakan dengan baik. Coachee mengorganisir para guru yang sudah terbentuk dalam tim MGMP dengan baik. Walaupun hasilnya belum begitu tampak perbedaan. Namun coachee dan tim sudah terorganisir dengan baik. Perbandingan nilai antara kondisi awal dan siklus I, dapat dilihat di tabel dan grafik di bawah ini:

Tabel 4.3. Perbandingan Kondisi Awal dan Siklus I

\begin{tabular}{lcc}
\hline \multicolumn{1}{c}{ Keterangan } & Kondisi Awal & Siklus I \\
\hline Persentase & $58,33 \%$ & $66,67 \%$ \\
Skor Maksimum & 4 & 4 \\
Skor Perolehan Tertinggi & 2 & 4 \\
Skor Perolehan Terendah & 2 & 3 \\
\hline
\end{tabular}

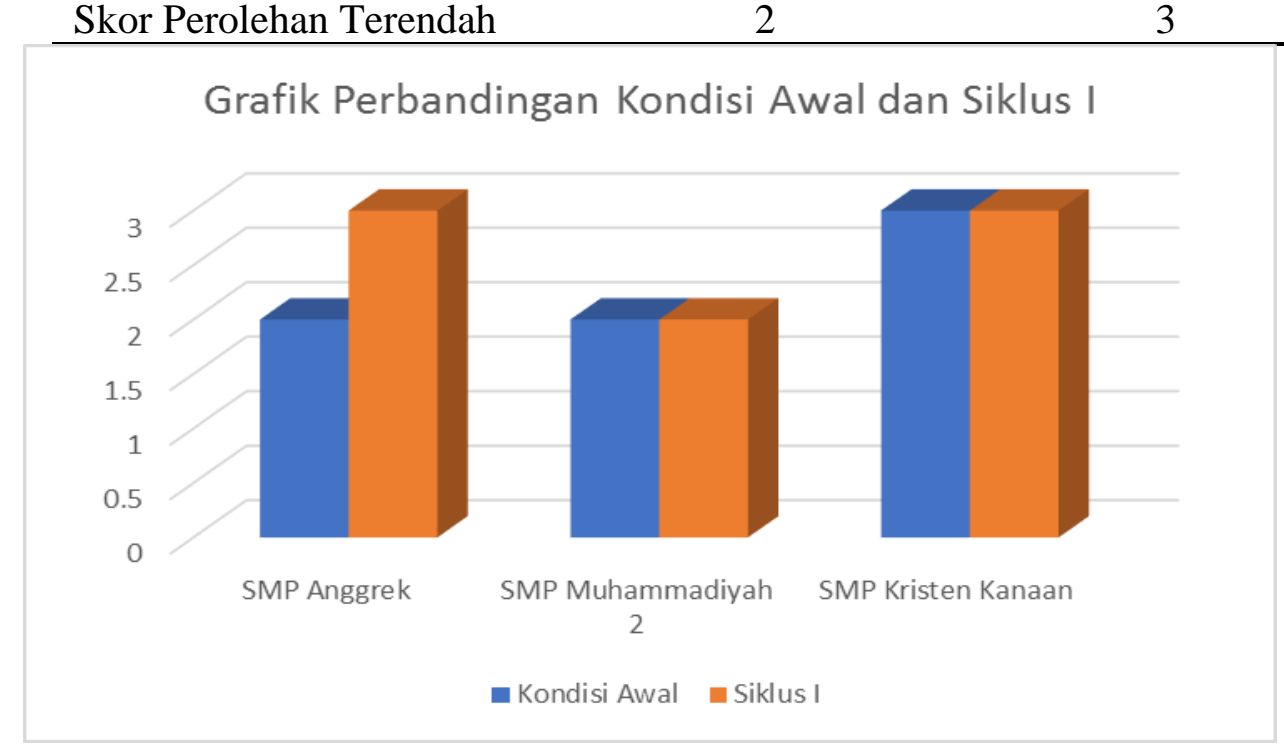

Gambar 4.2. Grafik Perbandingan Kondisi Awal dan Siklus I

\section{Siklus II}

Rangkuman hasil pengamatan pada siklus II, dapat dilihat pada pelaksanaan topik pelaksanaan supervisi akademik dan analisis data supervisi akademik sudah dilaksanakan dengan baik. Coachee dengan mudah dapat mengidentifikasi apa yang harus dilakukan bersama timnya dan hasilnya juga meningkat secara signifikan. Perbandingan nilai antara siklus I dan siklus II dapat dilihat pada Tabel 4.5 dan Gambar 4.3 di bawah ini,: 
Tabel 4.5. Perbandingan Siklus I dan Siklus II

\begin{tabular}{lcc}
\hline \multicolumn{1}{c}{ Keterangan } & Siklus I & Siklus II \\
\hline Persentase & $66,67 \%$ & $83,33 \%$ \\
Skor Maksimum & 4 & 4 \\
Skor Perolehan Tertinggi & 3 & 4 \\
Skor Perolehan Terendah & 2 & 3 \\
\hline
\end{tabular}

\section{Grafik Perbandingan Siklus I dan Siklus II}

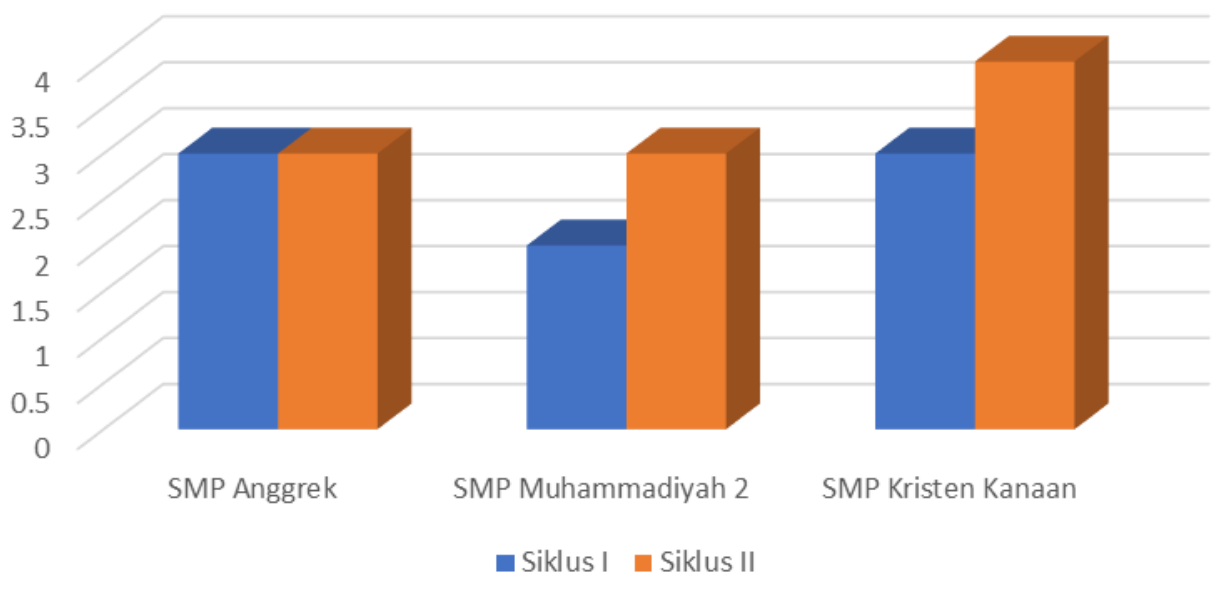

Gambar 4.3. Grafik Perbandingan Siklus I dan Siklus II

Berdasarkan capaian yang diperoleh pada siklus II, ternyata nilai rata-ratanya sudah memenuhi indikator keberhasilan yang ditetapkan dalam penelitian ini yaitu $\geq 80 \%$ sehingga penelitian dihentikan. Setelah itu, dilakukan pemberian umpan balik dan ucapan selamat dari coach kepada coachee atas kinerja yang sudah dilakukan yang telah memenuhi semua dokumen supervisi akademik. Coach tetap memotivasi coachee agar terus meningkatkan kapabilitasnya sebagai kepala sekolah.

\section{B. Pembahasan}

Dari sebelum dilakukannya tindakan sampai dilakukannya tindakan coaching, tantangan yang dihadapi dalam penelitian ini dapat diatasi dengan adanya arah dan tujuan yang jelas yang akan dicapai oleh coachee yang sudah ditegaskan pada siklus I, sehingga ketika coachee dan anggota tim PKG tidak melaksanakan tugasnya dengan tepat waktu, anggota tim lainnya memperingatkan untuk mengerjakan sesuai dengan waktu yang sudah ditetapkan bersama begitu juga dengan hal-hal lain yang berkenaan dengan tujuan yang akan dicapai pada proses coaching. Sehingga, pada setiap siklus dapat terlihat ada peningkatan penyelesaian tugas yang dapat dilihat dalam tabel dan grafik di bawah ini. 
Tabel 4.6. Perbandingan Kondisi Awal, Siklus I, Siklus II

\begin{tabular}{lccc}
\hline \multicolumn{1}{c}{ Keterangan } & Kondisi Awal & Siklus I & Siklus II \\
\hline Persentase & $58,33 \%$ & $66,67 \%$ & $83,33 \%$ \\
Skor Maksimum & 4 & 4 & 4 \\
$\begin{array}{l}\text { Skor Perolehan } \\
\text { Tertinggi }\end{array}$ & 2 & 2 & 3 \\
$\begin{array}{l}\text { Skor Perolehan } \\
\text { Terendah }\end{array}$ & 2 & 2 & 3 \\
\hline
\end{tabular}

Tabel di atas menunjukkan bahwa pada kondisi awal persentase kelengkapan dokumen supervisi akademik hanya 58,33\%. Pada siklus I mulai meningkat $66,67 \%$, Kemudian terjadi peningkatan pada siklus II menjadi $83,33 \%$, Peningkatan ini dapat terjadi dari hasil pertanyaanpertanyaan yang mengarahkan coachee dari coach yang dilakukan secara konsisten, terarah, dan terus menerus, serta coach tidak lupa memberi motivasi yang kuat sehingga kompetensi kepala sekolah dalam menyusun dan melaksanakan serta menilai dan menindaklanjuti supervisi akademik pun menjadi lebih baik.

Grafik Perbandingan Kondiai Awal, Siklus I dan Siklus II

\section{Grafik Perbandingan Kondisi Awal, Siklus I dan Siklus II}

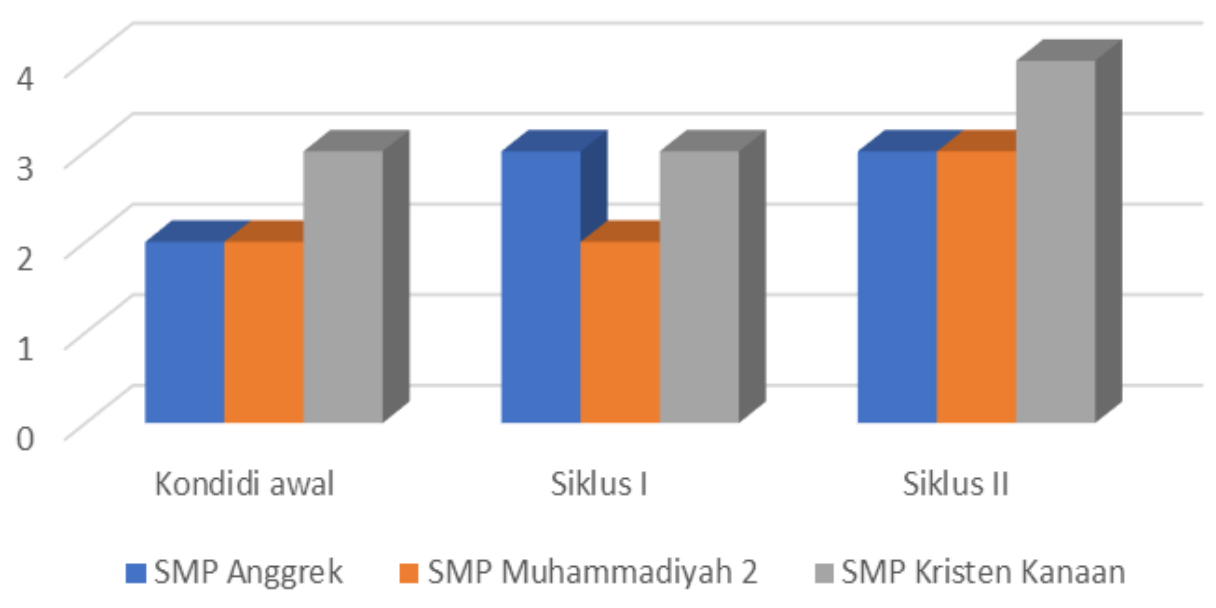

Gambar 4.4. Grafik Perbandingan Kondisi Awal, Siklus I, Siklus II dan Siklus III 


\section{A. Simpulan}

\section{SIMPULAN DAN SARAN}

Berdasarkan pembahasan dari hasil penelitian di atas, maka beberapa simpulan yang dapat ditarik adalah sebagai berikut :

1. Kompetensi kepala sekolah dalam supervisi akademik dapat ditingkatkan melalui coaching pada SMP binaan Dinas Pendidkan Kota Banjarmasin

2. Kepala sekolah dapat meningkatkan kemampuannya dalam menyelesaikan dokumen perencanaan dan melaksanakan supervisi akademik secara efektif dan efisien sesuai dengan jadwal yang sudah ditentukan bersama.

3. Kepala sekolah juga mampu menganalisis data dari hasil supervisi akademik dengan benar sampai dengan pemberian umpan balik dan pembuatan laporan.

4. Peningkatan penyelesaian dokumen juga sangat signifikan, terbukti dari hasil siklus I dapat dilihat bahwa peningkatan penyelesaian dokumen 66,67\% meningkat pada siklus II menjadi 83,33\%.

\section{B. Saran}

Dengan keberhasilan pelaksanaan "coaching" dalam supervisi akademik pada beberapa SMP binaan di Kota Banjarmasin dapat penulis sarankan sebagai berikut:

1. Pengawas sekolah diharapkan dapat menerapkan teknik coaching kepada kepala sekolah binaannya dalam melengkapi dan melaksanakan supervisi akademik di sekolah.

2. Agar para pengawas sekolah senantiasa melakukan berbagai inovasi dalam kegiatan pengawasan dalam rangka peningkatan kompetensi kepala sekolah yang pada gilirannya akan berdampak pada meningkatnya kualitas pembelajaran.

\section{DAFTAR RUJUKAN}

Arikunto, S., Suhardjono, \& Supardi. (2010). Penelitian Tindakan Kelas. Jakarta: PT. Bumi Aksara.

Departemen Pendidikan Nasional. (2009). Panduan Supervisi Klinis dan Evaluasi Pelaksanaan KTSP. Jakarta: Direktorat Jenderal Manajemen Pendidikan Dasar dan Menengah, Direktorat Pembinaan Sekolah Menengah pertama.

Glickman, C.D., Gordon, S.P., and Ross-Gordon, J.M. 2007. Supervision and Instructional Leadership A Development Approach. Seventh Edition. Boston: Perason.

Kementerian Pendidikan dan Kebudayaan. (2014a). Coaching. Jakarta: PSDMPK \& PMP.

Kementerian Pendidikan dan Kebudayaan. (2014b). Supervisi Akademik. Jakarta: PSDMPK \& PMP.

Kementerian Pendidikan Nasional. (2011). Buku Kerja Kepala Sekolah. Jakarta Pusat. Pusat Pengembangan Tenaga kependidikan. 
Peraturan Menteri Pendidikan Nasional Republik Indonesia No. 13 Tahun 2007 tentang Standar Kepala Sekolah/Madrasah.

Peraturan Pemerintah Nomor 74 Tahun 2008 tentang Guru

Peraturan Menteri Negara Pemberdayaan Aaparatur Negara dan Reformasi Birokrasi Nomor 21 Tahun 2010 Jabatan Fungsional Pengawas Sekolah dan Angka Kreditnya. Jakarta: Kemeneg PAN dan RB.

Permendikbud No. 143 Tahun 2014 tentang Petunjuk Teknis Pelaksanaan Jabatan Fungsional Pengawas Sekolah dan Angka Kreditnya.

Sergiovanni, T.J. 1982. Supervision of Teaching. Alexandria: Association for Supervision and Curriculum Development. 